\title{
Translating the transition: the translator-detective in Post-Soviet fiction
}

\author{
Brian James Baer \\ Kent State University
}

This article explores the ways in which the figure of the translator-detective in contemporary Russian literature functions to express and neutralize a range of fears and anxieties engendered by the post-Soviet transition. Tracing the roots of the motif of the translator in Russian literature back to F. M. Dostoevsky's Crime and Punishment, the paper then examines the translator-hero in the detective fiction of the best-selling contemporary authors Aleksandra Marinina, Boris Akunin, Dar'ia Dontsova, and Polina Dashkova. Representatives of the embattled Russian intelligentsia, their translator-detectives embody resistance to mindless cultural borrowing from the West.

\section{A borrowed genre}

One of the most striking features of the post-Soviet literary scene is the runaway success of detective fiction, as well as that of romance novels and action thrillers, testifying in the words of Nancy Condee and Vladimir Padunov (1995: 141) to the "wholesale social displacement of the cult of high culture". Anthony Olcott and Catherine Theimer Nepomnyashchy have argued that this striking re-orientation of the literary field is due in part to the fact that detective fiction serves a deep psychological need amidst the political, economic, and social turbulence of post-Soviet society, allowing Russians to "simultaneously express and neutralize" their fears and anxieties over soaring crime rates and the attendant transformation of comrades into criminal suspects (Nepomnyaschy 1999: 173). ${ }^{1}$ While the typical plot-line of the detective story, ending with the discovery and apprehension of the suspect, may serve to express and neutralize Russian fears produced by the phenomenal increase in crime that accompanied the fall of the Soviet Union and the transition to a market economy, the genre itself - "generally identified as an 'import' from the West" (Nepomnyashchy 1999: 162) - can be seen as an expression of another nexus of Russian anxieties: the loss of Russian identity and values in the face of Western cultural expansion.

The self-consciousness on the part of Russia's intellectual elite over its perceived "belated entry" onto the European cultural scene, dating back at least to Peter the Great's policy of forced Westernization, has taken on a new life since perestroika. An increase in poverty, political and economic instability, negative population growth, as well as Russia's loss of superpower status, all took place as the lifting of censorship restrictions produced a flood of Western cultural products on the Russian market. Detective 
novels were prominent among those products. As Nepomnyashchy (1999: 166) notes:

By the summer of 1991, hurriedly translated editions of the works of Western writers - foremost among them Agatha Christie and the British author of sensational crime fiction James Hadley Chase - had [. . .] begun to edge out the returning 'serious' literature of émigré and previously proscribed Soviet writers from the tables of street vendors in Moscow.

In the early 1990s, however, translated authors were supplanted by Russian authors of detective fiction, who made the genre their own, and in doing so helped to save the Russian publishing industry. The 'russification' of the genre achieved by such enormously popular authors as Aleksandra Marinina, Polina Dashkova, Boris Akunin, and Dar'ia Dontsova, actually became a theme in many novels, represented by, among other things, the figure of the translator-detective. Analysis of the genre suggests that the function of the polyglot detective hero is simultaneously to express and neutralize a specific set of post-Soviet anxieties inspired by the collapse of Soviet society and the resulting tidal wave of foreign influences.

\section{Translation as theme}

Since Russia's cultural turn to the West in the eighteenth century, translation has played a prominent role in Russian literary culture, and translation as a literary motif has a long history in Russian literature. Dostoevsky made great use of the motif as a way to frame the question of Russian national identity in the post-Petrine period. For the novelist, who first appeared in print as the translator of Balzac's Eugénie Grandet, the question was not whether or not to translate. As Vissarion Belinsky wrote in 1835: "It seems to me that especially now there needs to be in our literature an epoch of translations or, to put it better, all our literary activity should now be directed exclusively toward the translation of scholarly as well as literary works" (Belinsky 1960: 195). ${ }^{2}$ The question as Dostoevsky saw it was how to translate the foreign without compromising one's unique national identity. These issues were in fact central to the plot of his psychological detective novel, Crime and Punishment.

In that novel, the protagonist, Raskolnikov - whose name means 'schism' - is torn between contemporary Western philosophy and the 'Eastern' spiritual truths of Russian traditional culture. On an allegorical level, the two opposing sides of that philosophical schism are represented in gendered terms by the character Razumikhin, on the one hand, whose name derives from razum 'reason', and Sonia, the virtuous prostitute, whose full name, Sofiia, means 'holy wisdom'. ${ }^{3}$ Translation first appears as a realistic detail. Ruzumikhin, who "knew three European languages fairly well" (1999: 297), proposes that Raskolnikov help him with a translation of a progressive philosophical treatise from German, "Is Woman a Human Being?", in order to earn some money and because, as he puts it, his German 
is schwach (108). Within the spiritual/intellectual opposition organizing the novel, it is somewhat ironic that Razumikhin is offered the treatise to translate by a publisher named Kheruvimov, a name derived from the Russian for 'cherubim'. Declaring, "boy, does that stuff sell!" (107), Razumikhin suggests that he and Raskolnikov could then translate "some of the duller scandals" (107) from Rousseau's Confessions. Sensing Razumkhin's true motive to be pity, Raskolnikov returns the three-rouble advance, telling his friend: "I don't need translations" (108).

Razumikhin's cynical description of the translation business supports one of the novel's central themes, that progressive foreign, in particular, Western influences have an inordinate effect on a Russian elite that has been alienated from its native spiritual traditions. ${ }^{4}$ This point is made by the insightful detective Porfiry Petrovich, who explains to Razkolnikov: "Our cultivated man of today, you know, he'd sooner take the hoosegow than live with a bunch of foreigners like our peasants, he-he!" (324). A similar point is made by the cold, legal-minded Zaimatov, whose name is related to the Russian word for 'loan', zaem: "In a word, we have cut ourselves off irrevocably from the past, and I think that is something in itself..." (143). While Zaimatov celebrates the fact as evidence of the progress made by contemporary Russia, the thoroughly negative treatment of this character in the novel encourages a skeptical reading of the above passage.

The idea that Russians are alienated from their own culture is, of course, given its most dramatic expression in the crime committed by Raskolnikov, which was designed to prove that he was above the law according to theories he derived from his reading of radical Western philosophy. It is also echoed in the charge made intermittently throughout the novel that characters are "plagiarists" (162) and "parrots" (194), "not using his own words" (338); it culminates in Razumikhin's outburst directed at Raskolnikov: "If you were an authentic original instead of some translation from a foreign language... Well, you see, Rodia, I admit you're a clever guy, all right, but still you're a fool!" (162). Later, he insists:

Talk nonsense in your own way, that's almost better than talking sense in somebody else's. In the first case you're a man; in the second just a parrot! [...] We would rather live off other people's ideas - that's what we're used to! (194)

In the novel, the misguided desire to be original, to speak an authentically "new word", and the tendency "to value the human intellect above all things" (326) are paraphrased by Porfiry Petrovich as a desire to be a Napoleon, again associating it with the culture of Western Europe. In fact, Raskolnikov alludes to the Western origins of the atheistic philosophy of social Darwinism by using a phrase that appears in French in the original: "Crevez, chiens, si vous n'êtes pas contents" (219). This "new word" is later contrasted in the novel to the Bible or "eternal book" - whose status as a translation is, incidentally, ignored. 
In any case, Dostoevsky gives a far more positive view of translation in his later writings, in particular, his famous speech at the Pushkin monument in 1881, in which he describes Pushkin's genius as "the faculty of universal susceptibility, and fullest, virtually perfect reincarnation of the genius of alien nations" (1954: 960). ${ }^{5}$ This in turn reflects the proclivity of the Russian people "for universal susceptibility and all-reconciliation" (961), which will allow Russia "to reconcile all European controversies, to show the solution of European anguish in our humanitarian and all-unifying Russian soul" (980). Once the Russian people realizes that the "truth is within - not without - thee" (970), it will produce, not imitations or parodies, but reincarnations of alien genius that will enrich rather than distort Russia's unique national identity.

In his discussion of the translation of foreign cultures, Dostoevsky offers the psychological insight that, as long as the Russian elite continues to feel a sense of inferiority before Western Europe, it will borrow wildly, desperately, in the hope of 'catching up'. However, when firmly rooted in Russian culture, the Russian is capable of borrowing in such a way that leads not to the empty parroting of alien ideas, but to the creation of something truly new. In Dostoevsky's view, this kind of 'translation' would allow Russia to finally overcome her belatedness and assume a leading position in world culture. ${ }^{6}$

\section{The translator-detective}

Again faced with an onslaught of foreign, in particular Western influences, post-Soviet authors typically present their translator-heroes as a model for how to take in, or 'manage' the foreign. They are often contrasted to New Russian businessmen, who are presented as having lost touch with traditional Russian values in their race to be Western. As in Dostoevsky's writing, the question is not whether to take in foreign culture, but how to do it. Also, the sense that Russia has been pushed to the eastern periphery of the new Europe following the fall of the Soviet Union raises the question of Russia's unique position between East and West, which allows Russia, in Dostoevsky's formulation, to "interpret" the two cultures to one another.

\subsection{Boris Akunin: between East and West}

The charismatic hero of Boris Akunin's first series of detective novels, Erast Petrovich Fandorin, can be read as an embodiment of that Russian ability to take in foreign cultures - both Eastern and Western - while remaining entirely Russian. Fluent in a number of European as well as Asian languages, he has traveled both to America and to the Far East (his valet is Japanese), and is a brilliant master of disguise. While he speaks his native Russian with a stutter, a remnant of the traumatic death of his fiancée in a terrorist bombing, 
he speaks foreign languages with perfect fluency and in fact often 'passes' as a native speaker. Set in the final decades of the nineteenth century, Akunin's novels typically feature a variety of national types and the problem of cross-cultural communication is a central theme. In Azazel' ('Azazello'), for example, Fandorin is forced to travel to England and France in search of a suspect; Turetskii gambit ('The Turkish Gambit') takes place in Bulgaria during the Crimean War, and Leviafan ('Leviathan') on an international luxury cruise ship. The plot of Koronatsiia ('Coronation'), one of the later works in the series, unfolds during the coronation ceremonies for the last tsar, Nicholas II and features a French governess, a British nobleman (à la Oscar Wilde), French-speaking Russian aristocrats, and a Russian butler, Afanasii Ziukin, who will become Fandorin's sidekick.

Akunin's novels in the Fandorin series are imbued with a cosmopolitanism unthinkable in the Soviet period. Leviafan, for example, features upper-class passengers from France, England, Germany, Russia, and Japan, some of whom are monolingual and none of whom - except perhaps Fandorin himself - knows all of the languages on board, which, of course, necessitates translation. As Mrs. Truffaut says to her husband in English: "My darling, it must be awfully tiresome for you to translate all this nonsense" (2002: 113). The organizing principle of this novel, which takes place on board a luxury liner going from Southampton, England, to Calcutta, India, and concerns the theft of a rare statue of the Hindu goddess Shriva, is the confrontation (and mutual misapprehension) of East and West. When the ship lands in Port Said, Egypt, for example, Inspector Gauche comments: "The little city produced a rather strange impression - it was neither Asia nor Europe" (26).

Making visible various acts of translation supports the novel's broader theme of cultural (mis)understanding, for while most of the characters have traveled abroad, they have for the most part retained the prejudices of their respective nations and classes. Those prejudices are largely directed at one passenger, the novel's proverbial red herring, Mr. Auno, a Japanese samurai from Takugowa Japan, who has only recently assumed Western dress, but has yet to fully assimilate Western social behavior. This produces for the other characters on the ship the kind of disturbing dissonance between reality and appearance that fuels detective fiction. As the English passenger, Clarissa Stamp, puts it:

Of course, the yellow-skin peoples have their own moral foundation, but it is so foreign to Christianity that a normal person could never understand it. It would be better if they didn't wear European dress and didn't know how to use a knife and fork. This only creates the dangerous illusion of civilization, while beneath their black lacquered hair, parted down the middle, and their flat yellow brow, occur things that would be hard for us to imagine (104).

Akunin suggests a possible source for these stereotypes when he describes Renata Kleber reading a novel by the French globe-trotting author Pierre Loti, where she comes across the Japanese word ikebana ("the art of 
Japanese floral arranging'), suggesting that the novel is most probably Madame Chrysanthème from 1887, the tale of an American sailor who seduces and then abandons a Japanese woman (47), a story-line very familiar to opera-lovers, as it is also the plot of Puccini's Madame Butterfly (1904).

It turns out in the course of the novel that several of the passengers hold views of Russia very similar to those they hold of the Far East. As the Englishman, Reginald Milford-Stokes, writes in a letter to his wife: "You know, Emily, how I feel about Russia, that misshapen excrescence, covering half of Europe and a third of Asia. Russia aspires to spread its parodic form of Christianity and its barbaric customs over the entire world" (40). Fandorin is presented in the novel as an almost perfect embodiment of that union of East and West. Not only is he familiar with the Japanese language, he is well versed in Asian philosophy and customs, making him not only bilingual but thoroughly bicultural. Mr. Aono, sensing sympathy from Fandorin, gives the following assessment of the Russian as a cultural mediator:

The Russian diplomat has a profound, almost Japanese, mind. Fandorin-san possesses the non-European ability to see a phenomenon in its fullness, without getting bogged down in shallow details or technical minutiae. Europeans are unrivalled experts in everything that involves know-how; they excel in knowing how. While we, Asians, possess the wisdom, the understanding, of what for. (93)

Later on in his diary, he will add: "If Fandorin is skilled in observation, he owes this to the half-Asian essence of his homeland. Russia resembles Japan in many ways: the East reaching out toward the West" (94).

Intelligent and observant, Fandorin can see beyond appearances, which, in terms of language mediation, makes him a sense-oriented translator. For example, in Koronatsiia, when Ziukin suspects Lord Banville's English butler of being involved in the kidnapping of the grand duke because he said to Ziukin in Russian, with the aid only of a travel dictionary: "Ty ... smotret' ... luchshe ... segodnia" (you look (at) better today) (2000: 202), Fandorin takes the opportunity to teach his pupil something about translation. "Alas. You and Mister Freybee were the victims of literal translation (bukval'nyi perevod)" (322), Fandorin explains. The English butler, it turns out, had simply chosen the wrong Russian verb, smotret' ('to look at') rather than vygliadet' ('to look or appear'). Such linguistic diversions occur often in the works of Akunin, who was, before he took to novel writing, a much respected translator of Japanese literature under his real (Georgian) name, Gregorii Chkhartishvili.

While the traditional detective novel dramatizes the victory of reason - symbolized by the analytical detective à la Sherlock Holmes - over passion, Akunin's novels add another opposition. Almost all of the criminal masterminds in the Fandorin series are foreign, mostly Western European, and the ability of the Russian detective, who combines the best of Eastern and Western cultures, to unmask them replays for a Russian audience the 
victory of Russian insight over Western cunning. Moreover, Fandorin's brilliant analytical mind challenges stereotypes of Russians as a wild, emotional people.

\subsection{Dar'ia Dontsova and Polina Dashkova: between the Old and New Europe}

In Dar'ia Dontsova's “ironic detective novel”, Krutye naslednichki ('Hardboiled Heirs'), the heroine who solves the crime is a Russian teacher of French, educated but without pretensions, at once cultured and down-toearth. Divorced four times, she lives with an adolescent stepson from her second husband's first marriage, a young daughter from her fourth, and a menagerie of pets. While on a visit to France to see her closest friend, who married a homosexual French nobleman, she becomes entangled in a series of murders. There her ability to speak French and to understand French culture - as well as her self-deprecating sense of humor and sensible Russian upbringing - sets her apart from the other characters. Unlike her friend Natasha, who seeks wealth in the arms of a foreign husband ("All Russian women are idiots. Every foreigner is for us a Rothschild", 2003: 222-3), Dasha does not envy the wealthy aristocrats she encounters. Devoted to her pets, her daughter, and her friends, Dasha enjoys baking pirozhki and understands the problems that money can bring. In a sense, the novel stages the triumph of Dasha's cultural capital over the social and economic capital of the characters she meets in France.

Vera Saltykova, the heroine of Polina Dashkova's detective novel, Nikto ne zaplachet ('No One Will Weep'), is similar in character to Dontsova's Dasha, although she has never been married and lives with her mother. She is working as a free-lance translator from English and French when she unwittingly becomes involved in a murder. The independence of Dashkova's heroine, like that of Akunin's Fandorin and Dontsova's Dasha - none of them is officially employed by the police - highlights the incompetence of the police and other government authorities. As Anthony Olcott (2001: 146) notes:

Perhaps the most eloquent explorations of the collapse of the Russian state [...] come in the novels of Polina Dashkova. All of Dashkova's heroines are private persons who are thrust into danger either because of the state's incompetence, or because of its venality.

In fact, a central role in No One Will Weep is played by a vigilante, Volodia. A child of the intelligentsia like Vera, he arrives home from his mandatory military service to find that his entire family has been murdered during a robbery. In the power vacuum left by the fall of the USSR, he dedicates himself to hunting down and killing all those who do wrong. In general, Dashkova presents him in a very positive light. 
The complex plot of No One Will Weep takes place across the shifting political and linguistic landscape of the early post-Soviet period. The postSoviet transition is dramatized linguistically when Vera, after being assigned a new phone number, receives a fax written in a language she does not recognize. The language turns out to be Czech; the fax was written by Denis Kurbatov, the son of a Soviet diplomat and a concert pianist, who grew up with his brother, Anton, in Prague, a prestigious posting at the time. Had the Soviet Union survived, Denis and Anton would have lived with all the privileges of the nomenklatura. Instead, they find themselves second-class citizens in Prague, where Russian used to be a required subject: "Those who are now twenty studied Russian in high school. But a lot of twenty year olds don't want to speak the language. Even if their interlocutor doesn't know any other" (54). Their father eventually commits suicide and the two brothers struggle to make a go of a private business enterprise.

Desperate for capital, Denis makes off with a one thousand dollar advance for transporting drugs out of Turkey, which "they say is a European country, thought Denis, looking around, but there's nothing European here" (109). He disposes of the drugs and is then pursued by Skvozniak, the heartless product of a Soviet orphanage, who now heads a powerful mafia gang. The younger Kurbatov brother is eventually murdered, but not before he is able to fax a message to Anton, telling him the whereabouts of the money. However, their old business phone number has already been reassigned to Vera, who becomes the unwitting possessor of a key piece of evidence, written in a language she cannot understand.

On the surface, Vera would seem to be better equipped to succeed in the new post-Soviet world than the Kurbatov brothers. A straight-A student, she grew up "independent, responsible, and very neat" (31). She knows the new prestige languages - English and French - which allows her to work for international organizations that pay her international rates. However, it is in her personal life that she appears to be a victim of post-Soviet values: she does not fit the new ideals of beauty. She is short, somewhat overweight, and wears glasses that do not become her. "Everything is terrible", she laments. "Very soon I'll be thirty. I don't have a husband, children, or steady work. Last month I put on two kilos" (30). Her on-again, off-again lover, Stas Zelinsky, marries brainless models, but continues to ask Vera to translate things for his fledgling publishing business - for free. She scolds herself: "To him, you're just a fat dictionary, a desktop computer that he can turn on and off when he gets the urge" (30).

When Skvozniak discovers that Vera is in possession of Denis's fax, he decides to court her. Initially Vera accepts his advances and nearly accepts his proposal of marriage, despite the fact that her beloved Irish setter seems afraid of him and Sonia, the adolescent daughter of a friend, is deeply suspicious of him. Sonia attends the same special school (spetsshkola) for the study of foreign languages that her mother and Vera attended. However, the school has changed with the introduction of market capitalism. It is now filled with the children of New Russians, who get into the once competitive 
school with the help of generous bribes. Sonia's experience with these nouveaux riches allows her to interpret Skvozniak's behavior: "He attempted to hide his lack of education, his inner cruelty, and even criminal character. Sonia felt this a mile away thanks to her experiences in her elite school" (304). Later on, a police officer gives an assessment of post-Soviet youth that complements Sonia's observations:

“They're funny," Mal'tsev thought, "funny and stupid. In the time they spend hanging out in the hallway, smoking, drinking beer and flirting with one another, each of them could have learned two foreign languages, how to use a computer, banking, or some other useful thing". (385; italics mine)

In the end, the embattled intellectuals in the novel defeat the uneducated criminal mastermind. Volodia kills Skvozniak, but is fatally wounded himself. Stas, Vera's shiftless lover, also dies. Vera and Anton then go to Prague to see what valuables are hidden at the address contained in Denis's fax. The money they find turns out to be counterfeit, but true to their intelligentsia values, they "simply, without any emotion and without any further verification, leave the counterfeit bills and walk away" (444). That evening they spend the night together in Prague, in a sense reclaiming the Czech capital from the New Russians, among whom "it had become fashionable to own property in the Czech republic" (49).

\subsection{Alexandra Marinina: between fidelity and passion}

The opposition of the translator/intellectual to new Russian criminal/capitalists also structures the detective fiction of Alexandra Marinina, one of the best selling authors of the 1990s. The detective heroine in Marinina's novel Stilist (2002), Nastia Kamenskaia, knows five foreign languages and translates detective fiction from three. Unlike Vera Saltykova, however, Kamenskaia works full time as an analyst in the police department, and in general the police come off much better in Marinina's novels than they do in Dashkova's. In fact, Marinina often juxtaposes the dedication and relatively low pay of police detectives to the selfishness and greed of new Russian businessmen. The fact that Kamenskaia works for the prosecutor's office illustrates an allegiance to the social good over personal gain, as well as a relative lack of concern for money.

Kamenskaia in a sense embodies the post-Soviet transition. She remains an employee of the state, but earns money on the side as a translator. ${ }^{8}$ The economic inequalities of post-Soviet society, "the unfairness [...] in the way our present life is set up" (2002: 64), become strikingly evident when Kamenskaia comes into contact with an ex-lover, Solov'ev, who is a translator of Asian literature and the literary stylist of the novel's title. When Kamenskaia sees the beautiful home Solov'ev now owns, she comments somewhat bitterly that she could be living like Solov'ev had she not de-dicated her life to the police (62). When Kamenskaia meets Solov'ev's 
publishers, she classifies them as "typical new Russians, riding around in expensive, shiny foreign cars and never putting down their cell phones, nonchalantly discussing millions in credit and percentage rates" (35); she finds them condescending and rude. The detective's harsh assessment of the new Russians is, however, not surprising. On her first visit to Mechta ('The Dream'), the exclusive housing development outside Moscow where Solov'ev lives, she notes:

In general who lives in these expensive houses? 'New Russians', of course. The 'old' Russians couldn't afford it. [. . .] Among twenty families there were only three that had grandmothers and grandfathers living with them at Mechta to look after the children while their sons and daughters occupied themselves with business in their offices. (13)

The New Russians are presented as betraying the traditional 'family values' of Russian culture. In fact, Solov'ev himself is estranged from his only son, who lives a dissolute life in the family apartment in Moscow and has little to do with his crippled father. Inside the beautiful homes of the New Russians, Kamenskaia intimates, yawns a spiritual void. The moral lesson that, in Marinina's world, money does not buy happiness is further underscored by Solov'ev's depression and recurring panic attacks.

Kamenskaia eventually discovers that Solov'ev was crippled on orders from his New Russian publishers, who wanted to keep their "translator" from leaving Russia. It turns out that her ex-lover was more than a translator; he was a "stylist", transforming the compelling but poorly written plots of Japanese detective novels into Russian bestsellers. Kamenskaia puts this all together when she recognizes a passage in one of the translated novels: "A person with sad eyes - that's a person who never cried when he was cursed at and beaten" (369). She later comes upon the same passage in a folder in Solov'ev's office, confirming that this was Solov'ev's original writing! The passage appears in a translation of a Japanese novel, Klinok ('The Blade'), about the Japanese mafia in Hollywood, which symbolizes Russia's inbetweenness: the Russian bestseller was imagined by a Japanese author and set in America.

Marinina's novel, however, does not celebrate the kind of translation done by Solov'ev. ${ }^{9}$ The bestsellers he 'translates' are the product of vanity on the part of the Japanese author, of greed on the part of the Russian publishers, and of unseemly intervention on the part of Solov'ev himself. The translator's role in this publishing venture appears morally ambiguous, transforming an "ordinary humanist" (62) into a New Russian. ${ }^{10}$ Although Kamenskaia never discusses her own translation approach, we can assume, according to the logic of the novel, that she remains 'faithful' to the original, just as she remains faithful to her husband throughout the novel, rejecting the advances of her ex-lover, the stylist. No matter how many Western detective novels she translates, she never gives in to easy profits and remains true to her career as a detective and to her traditional Russian values. 


\section{Conclusion}

While not all the translator-heroes play an active role in unraveling mysteries (Vera Saltykova, for example, is simply the unwitting link bringing Kurbatov and Skvozniak together), they are all positive characters, representing not only the cultural mediation skills necessary to navigate postSoviet society, but also the traditional values of the Russian intelligentsia. When Anton strikes Skvozniak near the end of No One Will Weep with a paper weight that belonged to Vera's great-grandfather, the realistic detail suggests her intellectual pedigree, the continuity of her family tree, in stark contrast to that of Skvozniak, the orphan turned heartless criminal. While all of these novels assume that translation, and in a broader sense cultural borrowing, is a fact of life for Russians, they set up a morally charged opposition which contrasts the kind of borrowing that enriches one's identity, not only practiced but also embodied by the modest literary translator, to borrowing that fundamentally alters and distorts that identity, symbolized by the selfish and profit-obsessed New Russian.

\section{Bibliography}

\section{Primary texts}

Akunin, Boris (2000). Koronatsiia, ili poslednii iz romanov. Moscow: Zakharov. Akunin, Boris (2002). Leviafan. Moscow: Zakharov.

Akunin, Boris (2002). Turetskii gambit. Moscow: Zakharov.

Dashkova, Polina (2002). Nikto ne zaplachet: Roman. Moscow: Astrel'/Act.

Dontsova, Dar'ia (2003). Krutye naslednichki. Moscow: Eksmo.

Dostoevsky, Fyodor (1954 [1876-1881]). The Diary of a Writer (tr. Boris Brasol). New York: G. Brazilier.

Dostoevsky, Fyodor (1999 [1866]). Crime and Punishment (tr. Sidney Monas). New York: Signet Classic.

Marinina, Aleksandra (2002). Stilist. Moscow: Eksmo.

\section{Secondary texts}

Baer, Brian James (2005). "Engendering Suspicion: Homosexual Panic in the PostSoviet Detektiv". Slavic Review 64(1), 24-42.

Belinsky, Vissarion (1960 [1835]). "Znachenie perevodnoi literatury". Yu. Levin \& A. Fedorov (eds). Russkie Pisateli o perevode. Leningrad: Sovetskii Pisatel', 195.

Benjamin, Walter (1983). Charles Baudelaire: A Lyric Poet in the Era of High Capitalism (tr. Harry Zohn). London: Verso.

Condee, Nancy \& Vladimir Padunov (1995). "The ABC of Russian Consumer Culture: Readings, Ratings, and Real Estate". Nancy Condee (ed.). Soviet Hieroglyphics: Visual Culture in Late Twentieth-Century Russia. Bloomington: Indiana UP, 130-172.

Nepomnyashchy, Catherine Theimer (1999). "Markets, Murder, and Mayhem: Aleksandra Marinina and the Rise of the New Russian Detektiv". Adele 
Barker (ed.). Consuming Russia: Popular Culture, Sex, and Society Since Gorbachev. Durham: Duke UP, 161-191.

Olcott, Anthony (2001). Russian Pulp: The Detektiv and the Way of Russian Crime. Lanham, Maryland: Rowman \& Littlefield.

Wachtel, Andrew (1999). "Translation, Imperialism, and National Self-Definition in Russia”. Public Culture 11(1), 49-73.

1 This is in keeping with Walter Benjamin's observations to the effect that the detective novel was born out of the anxieties produced by the modern city: "Here [in the city] the masses appear as the asylum that shields an asocial person from his prosecutors. Of all the menacing aspects of the masses, this one became apparent first. It is at the origin of the detective story" (Benjamin 1983: 40).

2 Unless indicated otherwise, all translations are mine.

3 The association of the feminine with Eastern spirituality in Dostoevsky's writing is evident elsewhere when male characters embodying this spirituality are described as having feminine attributes. For example, of the detective Porfiry Petrovich, Dostoevsky (1999: 340) writes: "All he had to do was place the palm of his hand on his cheek and tilt his head to one side, and he would have looked completely like a woman".

${ }^{4}$ Later Razumikhin will suggest to Raskolnikov's mother and sister that he and Raskolnikov set up a translation business: "The mainstay of the enterprise is the fact that we'll really know what should be translated. We'll translate and publish and study all at the same time" (1999: 297).

5 Dostoevsky's concept of Russian culture as unifying all cultures is deeply indebted to German idealist philosophy.

${ }^{6}$ For an exploration of the imperialist implications of Dostoevsky's views on translation as elaborated in the Pushkin speech, see Wachtel (1999).

7 This novel was translated into English by Andrew Bromfield under the title The Winter Queen (2003).

8 Kamenskaia's 'inbetweenness', that is, her status as a cultural mediator is further underscored by the fact that she combines a variety of traditional male and female traits.

9 In an irony of history, Marinina's Stilist, featuring a rather unflattering portrayal of a translator of Japanese literature comes out as the fiction of Boris Akunin, himself a translator of Japanese literature, hits the market. Praised as a literary stylist, he eventually unseats Marinina as Russia's best-selling author of detective fiction.

${ }^{10}$ Marinina insinuates that in addition to being a closeted author, Solov'ev is a closeted homosexual. For more on the sexual dynamics of the novel, see Baer (2005). 